\title{
PENGARUH EFEKTIVITAS PENGENDALIAN MANAJEMEN DAN MOTIVASI TERHADAP KINERJA PERUSAHAAN (Studi Kasus Pada PERUM DAMRI Bandung)
}

\author{
Muhammad Dery Seftiansyah ${ }^{1)}$, Lestari Ramadanti²), Habib Akbar Muhammad ${ }^{3)}$ \\ Email: ${ }^{1)}$ deryseftiansyah09gmail.com, ${ }^{2}$ tari.ramadanti@gmail.com, ${ }^{3)}$ Habibakbar2343@gmail.com \\ ${ }^{1,2,3)}$ Program Studi Akuntansi Fakultas Ekonomi Institut Koperasi Indonesia
}

\begin{abstract}
Abstrak
Tujuan penelitian ini adalah untuk mengetahui bagaimana pengelolaan sumber daya manusia (SDM) pada perusahaan tersebut, untuk mengetahui seberapa besar pengaruh efektivitas pengendalian manajemen dalam memotivasi karyawan terhadap kinerja perusahaan di PERUM DAMRI dan mengetahui hambatannya. Metode penelitian yang digunakan ialah deskriptif kuantitatif. Populasi yang digunakan didalam penelitian ini yaitu seluruh karyawan Perum DAMRI yang ada di Kota Bandung. Metode analisis yang digunakan yaitu analisis regresi linier. Adapun hasil penelitian yaitu menunjukan bahwa pengendalian manajemen berpengaruh signifikan terhdap kinerja perusahaan dan motivasi berpengaruh signifikan terhadap kinerja perusahaan.
\end{abstract}

Kata Kunci: Efektivitas, Sistem Pengendalian Manajemen, Motivasi, Kinerja Perusahaan.

\begin{abstract}
The purpose of this study is to determine how the management of human resources $(H R)$ at the company, to find out how much influence the effectiveness of management control in motivating employees to the performance of the company in PERUM DAMRI and know the obstacles. The research method used is quantitative descriptive. The population used in this study were all employees of Public Corporation DAMRI in the city of Bandung. The analytical method used in linear regression analysis. It was found that management control has a significant effect on company performance and motivation has a significant effect on company performance.
\end{abstract}

Keywords: Effectiveness, Management Control System, Motivation, Company Performance.

\section{LATAR BELAKANG}

Perum Damri Bandung merupakan Badan Usaha Milik Negara (BUMN) yang bergerak di bidang jasa transfortasi. Awal didirikannya Perum Damri Bandung karena melihat masih kurang atau ketidakmerataannya jasa di bidang trasfortasi, dimana masih banyak masyarakat atau pemakai jasa transfortasi yang masih di sulitkan dengan kendaraan atau penyedia jasa transfortasi. Perum Damri Bandung juga menyediakan berbagai jasa trasfortasi seperti angkutan kota, antar kota, angkutan pariwisata, angkutan pemandu moda, dan angkutan perintis yang tentunya akan sangat memudahkan masyarakat atau pemakai jasa transfortasi tanpa perlu memikirkan kendaraan pribadi setiap bepergian atau ada keperluan. Tentunya dalam sebuah perusahaan pasti dibutuhkannya kerjasama baik karyawan dan peminpin perusahan.

Karyawan merupakan bagian penting dalam sebuah perusahaan dimana tidak akan tercapainya suatu tujuan jika tidak ada yang mengerjakan atau menjalankan pekerjaan dalam sebuah tujuan perusahaan, maka dari itu untuk meningkatkan motivasi kinerja karyawan dibutuhkan system pengendalian manajemen. dimana
Sistem pengendalian manajemen adalah suatu mekanisme secara formal didesain untuk menciptakan kondisi yang mampu meningkatkan peluang dan pencapaian harapan serta memperoleh hasil (output) yang diinginkan, dengan memfokuskan pada tujuan yang akan dicapai oleh organisasi dan perilaku yang diinginkan partisipan (Porporato: 2006).

Sistem Pengendalian Manajemen merupakan alat untuk menciptakan kerja sama, baik secara kolektif maupun individual unit organisasi dan menjadi saluran bagi berbagai upaya dan usaha yang dilakukan untuk mencapai tujuan spesifik suatu perusahaan. Pada dasarnya tujuan dari SPM ini adalah untuk memberikan informasi yang berguna dalam proses pengambilan keputusan, perencanaan dan evaluasi. (Gani, 2008). Kinerja merupakan suatu hasil yang harus diketahui dan dikonfirmasikan kepada pihak tertentu untuk mengetahui tingkat pencapaian target yang dihubungkan dengan visi dan misi perusahaan serta mengetahui dampak positif dan negatif dari suatu kebijakan operasional (Gani,2008). Salah satu alat organisasi yang penting untuk menunjang kinerja yang optimal dari sebuah perusahaan adalah dibutuhkannya suatu sistem pengendalian manajemen (Porporato, 2006). Sistem 
pengendalian manajemen berupa sistem beliefs, sistem boundary, sistem pengendalian diagnostik, dan sistem pengendalian interaktif berpengaruh secara positif dengan kapabilitas perusahaan yaitu orientasi pasar, inovasi, pembelajara organisasi, dan kewirausahaan (Lekatompessy, 2012).

Selanjutnya motivasi merupakan salah satu indicator yang dapat berpengaruh terhadap kinerja manajerial. Berdasarkan hasil temuan penelitian yang dilakukan oleh (Sulijaya \& Bangun, 2015) bahwa motivasi berpengaruh terhadap kinerja manajerial perusahaan.

kinerja yang tinggi memiliki beberapa karakteristik yaitu berorientasi pada prestasi, memiliki percaya diri, pengendalian diri, dan kompetensi. Karakteristik kinerja tersebut akan berpengaruh terhadap peningkatan motivasi kinerja karyawan karena SPM itu sendiri adalah sistem yang digunakan manajemen untuk mengendalikan agar tujuan suatu perusahaan dapat tercapai, maka diharapkan motivasi kinerja karyawan dapat meningkat dengan adanya SPM dan mempunyai motivasi yang tinggi dalam bekerja sehingga memberikan kinerja yang maksimal untuk tujuan perusahaan menjadi lebih baik. Penilaian terhadap pengaruh sistem pengendalian manajemen terhadap kinerja karyawan dalam upaya meningkatkan motivasi karyawan dapat berpengaruh secara signifikan, terhadap kinerja perusahaan karena dalam perusahaan jasa tranfortasi kinerja perusahaan dinilai dari: apakah telah memenuhi tingkat dimana pemakai penyedia jasa merapa puas dan apakah sistem dalam kerjasama karyawan baik; dan apakah motivasi kinerja karyawan meningkat dengan adanya sistem pengendalian manajemen.

Beberapa temuan penelitian yang telah mengkaji tentang topik yang sama dengan penelitian ini menghasilkan temuan yang berbeda atau masih adanya kesenjangan hasil penelitian (gap). Penelitian yang dilakukan oleh (Lekatompessy, 2012; Nurgahani, 2013) bahwa sistem pengendalian manajemen berpengaruh signifikan terhadap kinerja perusahaan. Hasil temuan ini berbeda dengan hasil temuan penelitian yang dilakukan oleh (Setiawan et al., 2016). Selanjutnya menurut (Sulijaya \& Bangun, 2015; Marbun et al., 2017) bahwa motivasi berpengaruh signifikan terhadap kinerja manejerial. Hasil temuan ini berbeda dengan hasil temuan penelitian yang dilakukan oleh (Rismayadi \& Maemunah, 2016) bahwa motivasi tidak berpengaruh signifikan terhadap kinerja perusahaan.

Berdasarkan pada uraian latar belakang dan perbadaan hasil penelitian yang telah diuraikan diatas, maka peneliti bertujuan untuk membuktikan secara empiris pengaruh system pengendalian manajemen dan motivasi terhadap kinerja perusahaan.

\section{METODE PENELITIAN}

\section{Jenis penelitian}

Penelitian ini menggunakan jenis penelitian deskriptif kuantitatif. Metode pengumpulan data yang digunakan dalam penelitian yaitu metode survey melalui instrumen kuesioner menggunakan pertanyaan tertutup.

\section{Populasi dan Sampel}

Populasi merupakan keseluruhan dari objek atau subjek ataupun individu pada suatu wilayah yang akan diteliti (Hamid \& Patra, 2019). Adapun populasi yang digunakan pada penelitian ini yaitu sebanyak 60 karyawan Perum Damri Bandung yang terdiri dalam bagian keuangan, bagian SDM, bagian teknik, bagian pariwisata, bagian order pemeriksaan. Sampel adalah kumpulan atau bagian dari populasi yang terpilih dengan prosedur tertentu yang bisa merepresentasikan populasi (Hamid \& Patra, 2019). Penentuan sampel pada penelitian ini menggunakan teknik purposive sampling. Ukuran sampel minimum dalam suatu penelitian adalah $10 \mathrm{x}$ jumlah variabel yang diteliti. Jumlah variabel yang diteliti dalam penelitian ini adalah 3 (variabel terikat + varaibel bebas), jadi ukuran sampel minimum untuk penelitian ini adalah $10 \times 3=30$. Sehingga jika peneliti mengambil sampel sebesar 34 responden berarti telah memenuhi ukuran minimum sampel untuk penelitian.

\section{Metode Analisis Data}

Adapun metode analisis data yang digunakan pada penelitian ini yaitu analisis regresi linier berganda formulasikan sebagai berikut.

$\mathrm{Y}=\mathrm{b}_{0}+\mathrm{b}_{1} \mathrm{X}_{1}+\mathrm{b} 2 \mathrm{X}_{2}+e_{i}$

Keterangan:

Y $\quad$ Kinerja Perusahaan

$\mathrm{b}_{0} \quad=$ Constant

$\mathrm{b}_{1}-\mathrm{b}_{2}=$ Koefisien Regresi

$\mathrm{X}_{1} \quad=$ Sistem Pengendalian Manajemen

$\mathrm{X}_{2} \quad=$ Motivasi

$e_{i} \quad=$ error

\section{HASIL DAN PEMBAHASAN}

\section{Hasil Uji Validitas dan Realibilitas}

Berdasarkan hasil analisis untuk uji validitas dan reliabilitas pada masing-masing variabel yaitu sistem pengendalian manajemen, motivasi, dan kinerja perusahaan disajikan pada tabel 1 . 
Tabel 1.

Hasil Uji Validitas dan Reliabilitas

\begin{tabular}{|c|c|c|c|c|c|c|c|}
\hline No & Variabel & Item & $\begin{array}{c}\text { sig. } \\
\text { hitung }\end{array}$ & alpha & $\begin{array}{c}\text { Cronbach } \\
\text { Alpha }\end{array}$ & \multicolumn{2}{|c|}{ Ket } \\
\hline \multirow{7}{*}{ 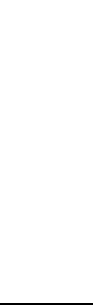 } & \multirow{7}{*}{ Sistem Pengendalian Manajemen } & SPM1 & 0.000 & \multirow{7}{*}{0.05} & \multirow{7}{*}{0.808} & Valid & \multirow{7}{*}{ Reliabel } \\
\hline & & SPM2 & 0.000 & & & Valid & \\
\hline & & SPM3 & 0.000 & & & Valid & \\
\hline & & SPM4 & 0.000 & & & Valid & \\
\hline & & SPM5 & 0.000 & & & Valid & \\
\hline & & SPM6 & 0.000 & & & Valid & \\
\hline & & SPM7 & 0.001 & & & Valid & \\
\hline & \multirow{12}{*}{ Motivasi } & M1 & 0.000 & \multirow{12}{*}{0.05} & \multirow{12}{*}{0.844} & Valid & \multirow{12}{*}{ Reliabel } \\
\hline & & M2 & 0.000 & & & Valid & \\
\hline & & M3 & 0.000 & & & Valid & \\
\hline & & M4 & 0.002 & & & Valid & \\
\hline & & M5 & 0.000 & & & Valid & \\
\hline & & M6 & 0.000 & & & Valid & \\
\hline & & M7 & 0.000 & & & Valid & \\
\hline & & M8 & 0.000 & & & Valid & \\
\hline & & M9 & 0.000 & & & Valid & \\
\hline & & M10 & 0.000 & & & Valid & \\
\hline & & M11 & 0.000 & & & Valid & \\
\hline & & M12 & 0.000 & & & Valid & \\
\hline & \multirow{9}{*}{ Kinerja Perusahaan } & KP1 & 0.001 & \multirow{9}{*}{0.05} & \multirow{9}{*}{0.762} & Valid & \multirow{9}{*}{ Reliabel } \\
\hline & & KP2 & 0.024 & & & Valid & \\
\hline & & KP3 & 0.000 & & & Valid & \\
\hline & & KP4 & 0.000 & & & Valid & \\
\hline & & KP5 & 0.000 & & & Valid & \\
\hline & & KP6 & 0.000 & & & Valid & \\
\hline & & KP7 & 0.000 & & & Valid & \\
\hline & & KP8 & 0.001 & & & Valid & \\
\hline & & KP9 & 0.000 & & & Valid & \\
\hline
\end{tabular}

Berdasarkan hasil uji validitas dan reliabilitas pada tabel 1, dapat diketahui bahwa untuk setiap item pertanyaan yang diajukan dalam penelitian keseluruhan terkategori valid dan reliabel. Dimana masing masing nilai signifikan hitung $<0.05$ dan nilai cronbach alpha untuk masing-masing variabel $>0.60$.

\section{Koefisien Determinasi}

Nilai koefisien determinasi digunakan untuk mengetahui besarnya proporsi dari variabel sistem pengendalian manajemen dan motivasi terhadap kinerja perusahaan.

Tabel 2.

Koefisien Determinasi/R Square

\begin{tabular}{ll|r|r|r} 
& & & \multicolumn{3}{c}{ Model Summary } \\
& & & $\begin{array}{c}\text { Adjusted R } \\
\text { Square }\end{array}$ & $\begin{array}{c}\text { Std. Error of } \\
\text { the Estimate }\end{array}$ \\
\hline Model & R & R Square & Squar \\
\hline 1 & $.793^{\mathrm{a}}$ & .629 & .605 & 2.320 \\
\hline
\end{tabular}

a. Predictors: (Constant), Motivasi Sistem Pengendalian Manajemen

b. Dependent Variable: Kinerja Perusahaan
Berdasarkan hasil analisis untuk nilai koefisisen determinasi pada tabel 2, diperoleh nilai R Square $\left(\mathrm{R}^{2}\right)$ sebesar 0.629 yang berarti bahwa variasi perubahan variabel kinerja perusahaan sebesar $62.9 \%$ secara bersama-sama disebabkan oleh variabel bebas yaitu sistem pengendalian manajemen dan motivasi, sedangkan sisanya sebesar 00 disebabkan oleh variabel lain yang tidak dimasukkan kedalam model regresi.

\section{Uji Simultan (Uji F)}

Uji simultan bertujuan untuk mengetahui apakah variabel bebas yang terdiri dari sistem pengendalian manajemen dan motivasi berpengaruh secara bersamasama terhadap kinerja perusahaan. 
Tabel 3.

Hasil Uji Simultan (Uji F)

\begin{tabular}{|c|c|c|c|c|c|c|}
\hline \multicolumn{7}{|c|}{ ANOVA $^{a}$} \\
\hline \multicolumn{2}{|c|}{ Model } & $\begin{array}{l}\text { Sum of } \\
\text { Squares }\end{array}$ & df & $\begin{array}{l}\text { Mean } \\
\text { Square } \\
\end{array}$ & $\mathrm{F}$ & Sig. \\
\hline \multirow[t]{3}{*}{1} & Regression & 282.883 & 2 & 141.442 & 26.274 & $.000^{\mathrm{b}}$ \\
\hline & Residual & 166.881 & 31 & 5.383 & & \\
\hline & Total & 449.765 & 33 & & & \\
\hline
\end{tabular}

a. Dependent Variable: Kinerja Perusahaan

b. Predictors: (Constant), Motivasi, Sistem Pengendalian Manajemen

Berdasarkan dari hasil analisis untuk uji secara simultan (Uji F) dapat diketahui bahwa nilai signifikan yang diperoleh lebih kecil dibandingkan dengan tingkat alpha 0.05. Dengan demikian secara bersama sama sistem pengendalian manajemen dan motivasi berpengaruh terhadap kinerja perusahaan.

\section{Uji Parsial (Uji t)}

Uji parsial (Uji t) digunakan untuk mengetahui tingkat signifikan antara variabel bebas dengan variabel terikat secara satu per satu.

\section{Tabel 4.}

Hasil Uji Parsial (Uji t)

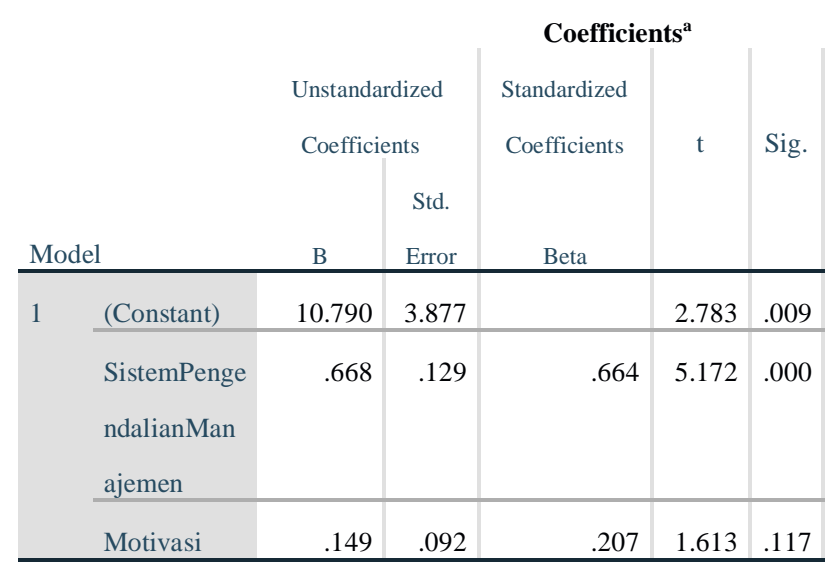

a. Dependent Variable: KinerjaPerusahaan

Berdasarkan hasil pengujian secara parsial (Uji t) dapat diperoleh informasi mengenai pengaruh masingmasing variabel bebas terhadap variabel terikat.

\section{Sistem Pengendalian Manajemen}

Berdasarkan dari hasil analisis dapat diperoleh informasi bahwa untuk nilai signifikan $<$ tingkat $\alpha=$ 0.05. dimana hasil ini memberikan informasi bahwa terdapat pengaruh positif dan signifikan sistem pengendalian manajemen terhadap kinerja perusahaan.

\section{Motivasi}

Berdasarkan dari hasil analisis dapat diperoleh informasi bahwa untuk nilai signifikan > tingkat $\alpha=$ 0.05. dimana hasil ini memberikan informasi bahwa terdapat pengaruh positif tetapi tidak signifikan motivasi terhadap kinerja perusahaan.

\section{Pembahasan Hasil Penelitian \\ Pengaruh Sistem Pengendalian Manajemen terhadap Kinerja Perusahaan.}

Berdasarkan pada hasil pengujian secara parsial (Uji t) yang menunjukkan bahwa variabel sistem pengendalian manajemen berpengaruh positif dan signifikan terhadap kinerja perusahaan dengan besaran nilai koefisien regresi 0.668 atau $66.8 \%$, artinya bahwa dengan meningkatnya sistem pengendalian manajemen akan diikuti dengan peningkatan kinerja perusahaan. Hasil temuan pada penelitian ini sejalan dengan hasil temuan yang dilakukan oleh (Lekatompessy, 2012; Nurgahani, 2013) bahwa sistem pengendalian manajemen berpengaruh signifikan terhadap kinerja perusahaan. Artinya, semakin baik sistem pengendalian manajemen yang dimiliki oleh perusahaan maka akan diikuti dengan peningkatan kinerja perusahaan.

\section{Pengaruh Motivasi terhadap Kinerja Perusahaan}

Berdasarkan pada hasil pengujian secara parsial (Uji t) yang menunjukkan bahwa variabel motivasi berpengaruh positif tetapi tidak signifikan terhadap kinerja perusahaan dengan besaran nilai koefisien regresi 0.149 atau $14.9 \%$, artinya bahwa dengan meningkatnya motivasi maka tidak akan diikuti dengan peningkatan kinerja perusahaan. Hasil temuan pada penelitian ini sejalan dengan hasil temuan yang dilakukan oleh (Rismayadi \& Maemunah, 2016) bahwa motivasi tidak berpengaruh signifikan terhadap kinerja perusahaan. Artinya, peningkatan motivasi karyawan belum mampu berdampak signifikan terhadap peningkatan kinerja perusahaan.

\section{PENUTUP}

\section{Simpulan}

Berdasarkan hasil analisis dan pembahasan yang telah diuraikan maka dapat disimpulkan beberapa poin penting dari penelitian ini, diantaranya yaitu:

1. Secara simultan variabel sistem pengendalian manajemen dan motivasi berpengaruh secara signifikan terhadap kinerja perusahaan.

2. Secara parsial (Uji t) variabel sistem pengendalian manaejmen berpengaruh signifikan terhadap kinerja perusahaan.

3. Secara parsial (Uji t) variabel motivasi berpengaruh signifikan terhadap kinerja perusahaan.

Saran

Berdasarkan hasil analisis dan pembahasan yang telah diuraikan maka dapat diusulkan sarang dari penelitian ini, diantaranya yaitu:

1. Berdasarkan hasil penelitian diperoleh informasi bahwa untuk variabel motivasi masih memiliki dampak yang tidak signifikan terhadap kinerja perusahaan. Tentunya informasi ini dapat dijadikan sebagai landasan bagi PERUM Damri Bandung untuk lebih memperhatikan motivasi yang dimiliki 
oleh karyawannya, misalnya melalui pemberian insentif, bonus dan pelatihan.

2. Untuk variabel sistem pengendalian manajemen yang memiliki pengaruh signifikan terhadap kinerja perusahaan, tentunya harus terus diupayaan untuk dipertahankan dan lebih ditingkatkan lagi untuk pencapaian kinerja perusahaan.

\section{DAFTAR PUSTAKA}

Hamid, R. S., \& Patra, I. K. (2019). PENGANTAR STATISTIKA UNTUK RISET BISNIS DAN EKONOMI Konsep Dasar dan Aplikasi SPSS versi 25. Banten: CV. AA. RIZKY.

Lekatompessy, J. E. (2012). PERAN SISTEM PENGENDALIAN MANAJEMEN DALAM MENINGKATKAN KINERJA PERUSAHAAN : Analisis Kontinjensi dan Resource-Based View DISERTASI Jantje Eduard Lekatompessy PROGRAM STUDI DOKTOR ILMU EKONOMI. Peran Sistem Pengendalian Managemen, 194.

Marbun, R., Ratnawati, V., \& Silfi, A. (2017). Pengaruh Penerapan Total Quality Management Sistem Pengukuran Kinerja Sistem Penghargaan Motivasi dan Komitmen Organisasi terhadap Kinerja Manajerial (Studi Empiris pada Perhotelan di Pekanbaru). 4(1), 572-585.

Nurgahani, T. (2013). Pengaruh Sistem Pengendalian Manajemen dan Pengendalian Internal terhadap Kinerja Perusahaan (Studi Kasus pada PT Kawikarya Wisman Graha Tanjung Pinang). Skripsi. Falkutas Ekonomi. Universitas Maritim Raja Ali Haji.

Rismayadi, B., \& Maemunah, M. (2016). Pengaruh Motivasi Kerja, Kepemimpinan dan Budaya Organisasi Terhadap Kepuasan Kerja Karyawan serta Dampaknya pada Kinerja Perusahaan (Studi kasus pada PT. Concord Indonesia). Jurnal Manajemen \& Bisnis Kreatif, 2(1), 124-135. https://doi.org/10.36805/manajemen.v2i1.181

Setiawan, I., Titisari, K., \& Wijayanti, A. (2016). Pengaruh Sistem Akuntansi Manajemen dan Sistem Pengendalian Manajemen Terhadap Kinerja Manajerial di Lorin Group.

Sulijaya, F., \& Bangun, N. (2015). Pengaruh Total Quality Management, Motivasi dan Komitmen Organisasi terhadap kinerja manajerial pada pt sekar bumi, tbk. Jurnal Akuntansi, 19(3), 433448. 